International Journal of Social Inquiry Cilt/ Volume 14 Sayı / Issue 12021 ss./pp. 81-112

\title{
ÖĞRETMEN ADAYLARININ ÖĞRETMENLİK MESLEĞİNE İLIŞKINN KAYGILARININ BELİRLENMESİ
}

\section{Ebru KÜLEKÇİ AKYAVUZ*}

Makale Geliş Tarihi-Received: 06.08.2020

81

Makale Kabul Tarihi-Accepted: 25.02.2021

DOI: $10.37093 /$ ijsi.950548

ÖZ

Çalışmanın amacı öğretmen adaylarının öğretmenlik mesleğine ilişkin kaygılarının belirlenmesidir. Ayrnca bu kaygıların en aza indirilmesi için ne tür uygulamalarm yapılabileceğinin tespit edilmesi de bu çalışma kapsamında amaçlanmıştır. Çalışma nitel araştırma olarak tasarlanmıştır. Nitel araştırma desenlerinden betimleyici fenomenolojik desen tercih edilmiştir. Araştırmanın çalışma grubunu Kilis 7 Aralık Üniversitesine kayıtlı 20 öğretmen adayı oluşturmaktadır. Amaçlı örneklem çeşitlerinden ölçüt örneklem yöntemi kullanılarak örneklem seçimine gidilmiştir. Yarı yapılandırılmış görüşme formu hazırlanarak veriler toplanmıştır. Araştırmada elde edilen veriler betimsel analiz yöntemi ile analiz edilmiştir. Araştırmanın sonucunda öğretmen adaylarının mesleğe yönelik kaygıları; bireysel kaygılar, öğretim süreci ile ilgili kaygılar, öğrenci merkezli kaygılar ve kurumsal kaygılar başlıklı 4 (dört) tema olarak belirlenmiştir. Öğretmen adaylarmin kaygilarn sebebi olarak da yeterli deneyime sahip olmamaları, bilgi eksikliği yaşamaları, kişisel özellikleri gibi birçok sebep olduğu sonucuna ulaşılmıştır.

Anahtar Sözcükler: Öğretmen Adayı, Kayg1, Öğretmenlik Mesleği, Eğitim, Görüş.

Jel Kodu: I 230.

* Dr. Öğr. Üyesi, Kilis 7 Aralık Üniversitesi, Eğitim Bilimleri Bölümü, Ĕ̆itim Yönetimi Anabilim Dalı, Kilis/Türkiye. ebrukulekci@kilis.edu.tr, https://orcid.org/0000-0002-2436-8761. 


\title{
IDENTIFYING THE CONCERNS OF CANDIDATE TEACHERS REGARDING TEACHING PROFESSION
}

\begin{abstract}
The aim of this study is to identify the concerns of candidate teachers concerns about teaching profession. In addition, the purpose of this study is to determine the reasons for the concerns of candidate teachers and what kind of practices could be carried out in order to minimize these concerns. The study was designed as qualitative research. Descriptive phenomenological design was preferred among qualitative research designs. The study group consisted of 20 candidate teachers enrolled in Kilis 7 Aralı University. Sample selection was made by using criterion sampling method among the purposive sampling types. A semi-structured interview form was prepared to determine the candidate teachers' concerns about their profession. The data obtained in the study were analyzed with descriptive analysis method. In this context, 4 themes were identified: individual concerns, teaching-related concerns, student-centered concerns and institutional concerns. In general, candidate teachers stated that they did not have sufficient experience as a reason for their concerns, that their pedagogical knowledge was insufficient and that their personality structures were effective.
\end{abstract}

Keywords: Candidate Teacher, Concern, Teacher Profession, Education, View.

Jel Code: I 230. 


\section{Ö ğretmen Adaylarının Öğretmenlik Mesleğine İlişkin \\ Kaygılarinin Belirlenmesi}

\section{GİRIŞ}

Toplumsal süreç içerisinde oluşan birçok değiş̧iklikler, teknolojinin gelişmesi, sosyal, kültürel, ekonomik faktörler bunlara bağlı olarak yaşam içerisinde var olan belirsizlikler bireylerin geleceğe ilişkin kaygı düzeylerini artırmaktadır. Türk Dil Kurumu (TDK)'na göre kaygı; gam, üzüntü, tasa, endişe edilen düşünce olarak ele alınmakla birlikte genellikle kötü bir şey olacakmış düşüncesinden kaynaklı, nedeni belli olmayan gerginlik duygusu olarak tanımlanmaktadır (TDK, 2019). Bireyler kaygıyı gelecekle ilgili umutsuzluk, başarısızlık, karamsarlık, endişe şeklinde karmaşık tepkilerle birlikte ifade etmektedirler (Göçmen ve Balgamış, 2005). Kaygı hissinin sahip olduğu bu tepkiler insan hayatını olumsuz olarak etkileyip bireyin yaşam kalitesinin düşmesine (Sadıkoğlu, Hastürk ve Polat, 2018) ve bireyin yaptığı işlerde motivasyonunun azalmasına neden olabilmektedir. Kaygı, her meslekte olduğu kadar öğretmenlik mesleğinde de oluşabilmektedir. Her meslek dalının mesleği icra eden bireylerden beklentileri söz konusudur. Gelecek nesillerin yetişmesinde önem arz eden öğretmenlik mesleğinde de öğretmen ve öğretmen adaylarından beklentiler mevcuttur. $\mathrm{Bu}$ beklentilerin karşılanamaması öğretmenlerde bazı kaygılara sebebiyet vermektedir.

Bir toplumun geleceğini teminat altına almasında eğitim, kuşkusuz bir öneme sahiptir. Toplumun refah seviyesine ulaşması, sosyal, kültürel değerlerinin korunması, toplumsal bütünleşmenin sağlanması, bireylerin toplumsal değerleri kazanarak toplumla uyumlu hale gelmesi genelde eğitim, özelde ise öğretmenlerin nitelikli olmasına bağlıdır. Bir sistem olarak eğitimin en temel öğesi öğretmendir (Şişman, 2007). Öğretmenin karakteri, mesleki anlamda yeterli olması ve öğrencilerine yönelik olumlu bir tutum sergilemesi (Ensari, 2000) toplumun ihtiyaç duyduğu nitelikli bireylerin yetiştirilmesini sağlayacaktır. Bu noktada öğretmenlik mesleğinin etkili bir şekilde yürütülmesi gerekmektedir.

Öğretmenlik mesleği, eğitimle ile ilgili olan bilimsel, kültürel, sosyal ve ekonomik boyutları kapsayan alana özgü uzmanlık bilgi, becerisi ve yeterliği temel alan pedagojik formasyon ve akademik çalışma gerektiren, profesyonel düzeyde bir uğraşıdır (Erden, 1998). Öğretmenlik mesleği, alan bilgisinin yanında genel kültür, öğretmenlik bilgi, beceri, yeterlik ve bireylerin öğretmenlik mesleğine yatkınlığına bağlıdır. Mesleğin gerektirdiği beklentiler ve öğretmenlik 
mesleğinde karşılaşılacak zorluklar özellikle mesleğe henüz başlamayan öğretmen adaylarında kaygı ve endişelere sebebiyet vermektedir. Zor bir süreçten sonra üniversite hayatına başlayan öğretmen adayları eğitimleri ve meslekleri ile ilgili endişeli olabilmektedirler. Bu süre zarfında iş bulma korkusu, iş seçimi, gerçek hayattaki rollerle ilgili düşünceler, arkadaşlık ilişkileri kaygı oluşturan faktörlerden bazıları olarak sıralanabilir (Tümerdem, 2007). Öğretmen adaylarının büyük çoğunluğunun mezuniyet sonrasında yapılan sınavlar ve iş bulamama, öğrenci ve velilerle iletişim kurma ve sınıf yönetimi ve disiplini sağlama, kendi kültürlerinden dolayı dışlanma, göreve başlayacakları bölgenin kültürüne uyum sağlamakta zorlanma

84 gibi sorunlarla karşılaşabileceklerine dair birçok kaygı yaşadıkları yapilan araştırmalar sonucu tespit edilmiştir (Aktaş, 2016, Atmaca, 2013; Çakmak ve Hevedanlı, 2004; Kaya ve Büyükkasap, 2005; Sever, Aktaş, Şahin ve Tunca, 2015). Fuller bu oluşabilecek kaygıları benmerkezli kaygılar, görev-merkezli kaygılar ve öğrenci-merkezli kaygilar olmak üzere üç kategori haline getirmiştir (Fuller, 1969; Smith, 2000): Ben-merkezli kaygıların merkezinde bireyin kendisi yer almaktadır. Ben-merkezli kaygılar taşıyan bir öğretmen adayı, öğretmenlik mesleğini başarılı bir şekilde yapıp yapamayacağına dair endişeler taşır. $\mathrm{Bu}$ endişeler öğretmen adaylarının yoğun bir stres durumu yaşamalarına neden olmaktadır. Görev-merkezli kaygıların merkezinde, bireyin öğreticilik kimliği yer almaktadır. Görevmerkezli kaygıları olan bir öğretmen adayı, öğrencilerine başarılı bir şekilde öğretebilme kaygısı taşımaktadırlar. Bu sebeple öğretim, yöntem ve teknikleri nasıl kullanacağı, nasıl materyal hazırlayacağı konusunda kaygılar duymaktadırlar. Öğrenci-merkezli kaygıların merkezinde ise öğrenciler yer almaktadır. Öğrenci-merkezli kaygıları olan öğretmen adayı, öğrenci ihtiyaçları ile ilgili kaygı taşımaktadır. Öğrenci-merkezli kaygıları olan öğretmen adayı, her öğrencinin duygusal, zihinsel ve sosyal ihtiyaçlarını en iyi şekilde karşılayabileceğine dair kaygı duymaktadır.

Öğretmen adaylarının karşılaştıkları zorluklar ve kaygılarının kaynağı hakkında bilgi edinilmesi, bu zorluk ve kaygıların çok geçmeden çözüme kavuşturulması açısından önem arz etmektedir (Doebler \& Roberson, 1987). Öğretmen adaylarının mesleklerine etkili bir şekilde başlamalarında mesleki kaygılarından arınmış olmaları gerekmektedir (Taşğın, 2006). Gelecek neslin şekillenmesine katkı sağlayacak öğretmen adaylarının hizmet öncesinde mesleğe yönelik ne tür kaygılar taşıdıklarının belirlenmesi ve bu kaygıların 


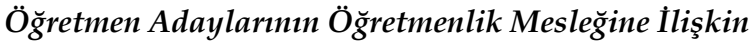 \\ Kaygılarınin Belirlenmesi}

giderilmesine yönelik ne tür uygulamaların yapılacağına dair önleyici çalışmaların yapılması açısından bu çalışma dikkate değer görülmektedir. Bu çalışmada öğretmen adaylarının öğretmenlik mesleğine ilişkin kaygılarının belirlenmesi ve bu kaygıların en aza indirilmesi için ne tür uygulamaların yapılabileceğinin tespit edilmesi amaçlanmıştır. Bu amaç doğrultusunda çalışmada cevap aranacak sorular şu şekildedir:

1. Öğretmen adaylarının öğretmenlik mesleğine ilişkin kaygıları nelerdir?

2. Öğretmen adaylarının mesleki kaygılarının nedenleri nelerdir?

\section{YÖNTEM}

\subsection{Araştırmanın Modeli}

Çalışma nitel araştırma olarak tasarlanmıştır. Nitel araştırma desenlerinden betimleyici fenomenolojik desen tercih edilmiştir. Betimleyici fenomenolojik desen bireylerin bakış açısına göre deneyim ve algılarını ortaya koymayı amaçlayan bir araştırma desenidir (Ersoy, 2016). Bu araştırmalar kesin ve genellenebilir sonuçlar ortaya koyma amacı taşımamaktadır (Yıldırım ve Şimşek, 2018). Fenomenolojik araştırmalar, bireylerin karşılaştıkları fenomenlerle ilgili olarak neyi algılayıp anladıkları ve deneyimlerinin neler olduğu ile ilgilenmektedir (Çekmez, Yıldız ve Bütüner, 2012). Bu araştırmada da öğretmen adaylarının görüşleri doğrultusunda öğretmenlik mesleğine ilişkin yaşadıkları kaygılar tespit edildiği için betimleyici fenomenolojik desen tercih edilmiştir.

\section{2. Çalışma Grubu}

Araştırmanın çalışma grubunu 2019-2020 eğitim öğretim yılı güz döneminde Kilis 7 Aralık Üniversitesine kayıtlı 20 öğretmen adayı oluşturmaktadır. Amaçlı örneklem çeşitlerinden ölçüt örneklem yöntemi kullanılarak örneklem seçimine gidilmiştir. Öğretmen adaylarının seçiminde ölçüt, öğretmen adaylarının son sınıf olmaları ve öğretmenlik uygulaması derslerini alıyor olmaları şeklinde belirlenmiştir. $\mathrm{Bu}$ ölçütün belirlenmesinin sebebi öğretmen adaylarının öğretmenlik uygulamaları derslerinde öğretmenlik 


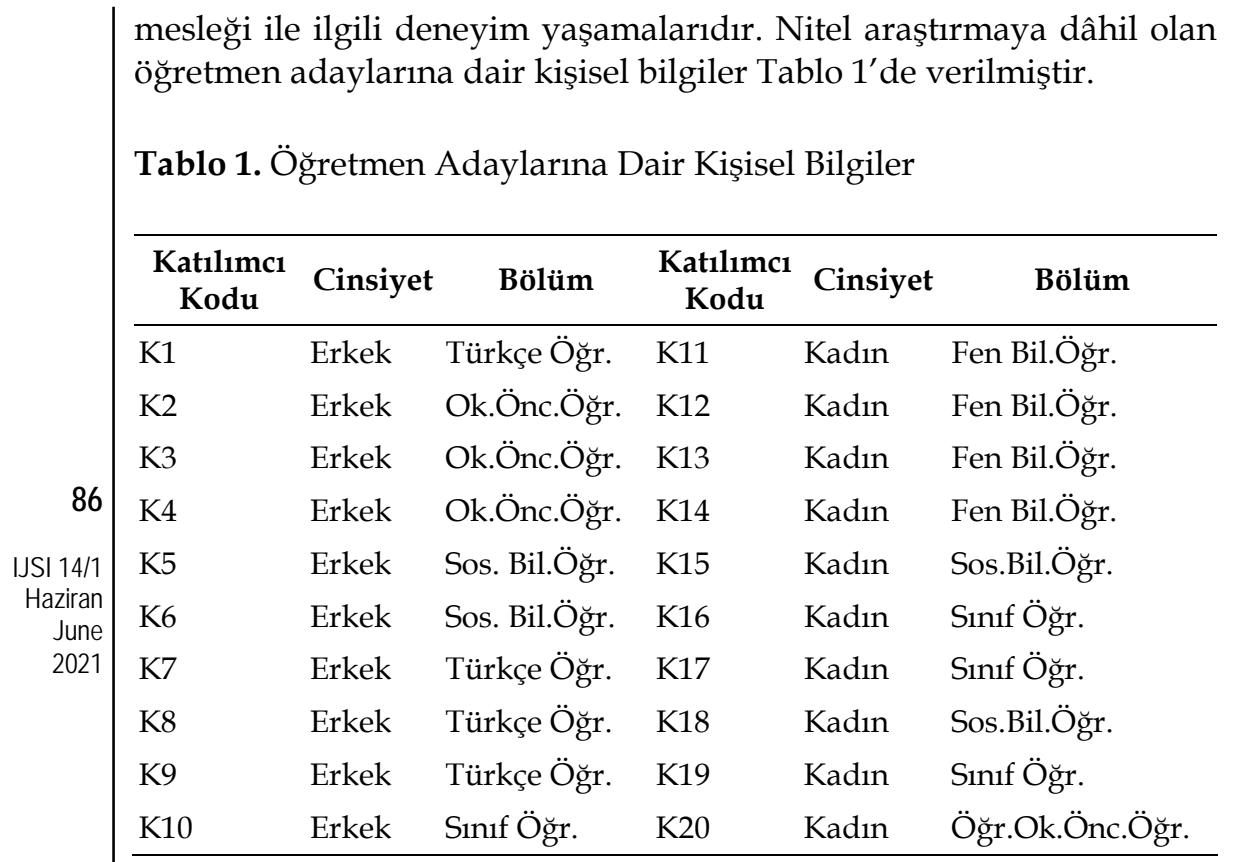

Tablo 1 incelendiğinde çalışma grubunun 10'u erkek, 10'u kadın öğretmen adayından oluştuğu ve Türkçe öğretmenliği, Sosyal Bilgiler öğretmenliği, Sınıf öğretmenliği, Fen Bilgisi öğretmenliği ve Okul Öncesi öğretmenliği şeklinde her anabilim dalından 4 öğretmen adayından oluştuğu görülmektedir. Çalışmada kolaylık sağlaması adına her bir katılımcıya (K1, 1. Kişi) belli kodlar verilmiştir.

\subsection{Verilerin Toplanmas1}

Araştırmaya başlamadan önce Kilis 7 Aralık Üniversitesi Etik Kurulu'ndan (Karar no: 2020/08) ve Kilis 7 Aralık Üniversitesi Rektörlüğü'nden gerekli izinler alınmıştır. Öğretmen adaylarının mesleklerine yönelik kaygılarını belirlemek amacıyla yarı yapılandırılmış görüşme formu hazırlanmıştır. Görüşme formu araştırmacı tarafından hazırlanmıştır. Görüşme formu hazırlanırken alan taraması yapılmış ve 4 soru olarak görüşme formu hazırlanmıştır. Öğretmen yeterlikleri alanında çalışmış bir uzmandan görüş alınmıştır. Uzman görüşü doğrultusunda kaygının sonucuna yönelik sorular formdan çıkarılıp toplam 2 ana soru ve 4 sonda soru 


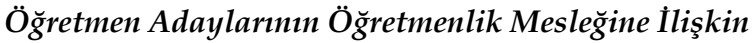 \\ Kaygılarinin Belirlenmesi}

şeklinde formun son haline karar verilmiştir.. Görüşme formunda öğretmen adaylarına yönlendirilen sorulardan bazıları şunlardır:

1). Öğretmenlik mesleğine ilişkin duyduğunuz kaygılarınız nelerdir? Açıklayabilir misiniz? (Ana soru)

2). Öğrencilerle ilgili ne tür kaygılar yaşıyorsunuz? (Sonda soru)

3). Öğretmenlik mesleğine ilişkin kaygılarınız altında yatan sebepler nelerdir?

Soruların anlaşılabilirliğini ölçmek amacıyla Okulöncesi öğretmenliği ve Türkçe öğretmenliği bölümlerinden iki öğretmen adayı ile pilot uygulama yapılmıştır. Soruların anlaşılabilirliğinde herhangi bir sorun yaşanmaması üzerine asıl uygulamaya geçilmiştir.

Araştırmanın verileri 2019-2020 eğitim öğretim yılı güz döneminde toplanmıştır. Görüşme soruları hazırlandıktan sonra farklı bölümlerden öğretmen adayları belirlenmiştir. Öğretmen adayları belirlenirken farklı bölümlerden ve farklı cinsiyetlerden eşit oranda olmasına dikkat edilmiştir. Öğretmen adaylarının ve araştırmacının uygun olduğu zaman dilimlerinde randevular ayarlanarak görüşmeler gerçekleştirilmiştir. Görüşme esnasında katılımcıların onayı alındıktan sonra ses kayıt cihazı kullanılmışır. Katılımcılardan herhangi olumsuz bir tepki gelmediğinden tüm görüşmeler ses kayıt cihazı ile toplanmıştır. Her bir öğretmen adayı ile görüşmeler yaklaşık 35-45 dakika arasında gerçekleşmiştir. Görüşme araştırmacının ofisinde yapılmıştır. Görüşmeler yapıldıktan sonra ses kayıtları hemen bilgisayara aktarılmış bir iki gün içerisinde katılımcılara mail atılarak verdikleri bilgilerin doğruluğu hakkında geri dönüt alınmıştır. Katılımcıların onayı alındıktan sonra analiz işlemine geçilmiştir.

\subsection{Verilerin Analizi}

Araştırmada elde edilen veriler betimsel analiz yöntemi ile analiz edilmiştir. Betimsel analizde elde edilen veriler, daha önceden belirlenen temalara göre özetlenip yorumlanmaktadır (Yıldırım ve Şimşek, 2018). Bu çalışmada da Fuller (1969)'in öğretmen adayları için belirlediği kaygı türleri dikkate alınarak temalar oluşturulmuştur. 


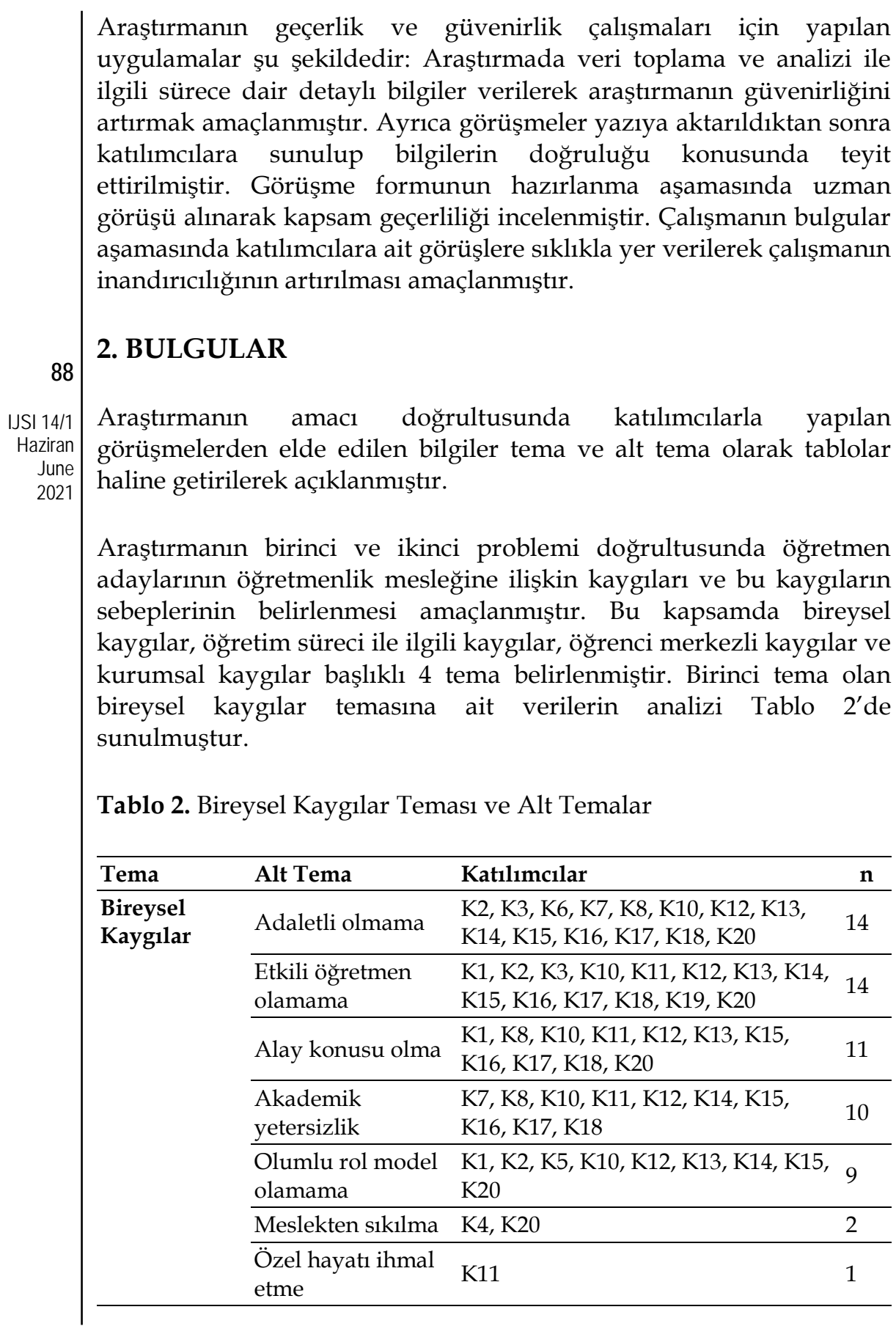




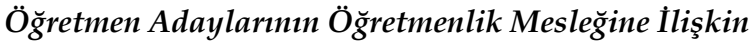 \\ Kaygılarinin Belirlenmesi}

Öğretmen adaylarının öğretmenlik mesleğine yönelik bireysel kaygılar teması adaletli olamama (14), etkili öğretmen olamama (14), alay konusu olma (11), akademik yetersizlik (10), olumlu rol model olamama (9), meslekten sıkılma (2) ve özel hayatı ihmal etme (1) alt temalarından oluşmaktadır. Görüşme yapılan öğretmen adaylarının çoğunluğu adaletli olamama ve etkili öğretmen olamama kaygılarını taşıdığını ifade etmişlerdir. Bu konu ile ilgi öğretmen adaylarının görüşleri şu şekildedir:

"Özel ilgiliye ihtiyacı olan öğrencilerle daha çok ilgilenirim aksi takdirde vicdan azabı çekerim. (K2)"; "Akılll, uslu, zeki öğrencilere daha çok ilgi gösteririm. (K3)"

"Çok adil değil biliyorum ama çalışkan öğrencileri daha çok severim. (K7)";

"Çok sevdiğim öğrencileri kayırmaktan korkuyorum. (K10)"

"Benim gözümde kızlar daha akıllı ve söz dinleyen olduklar için adil olmayabilirim. (K12)"

"Bana ayrım yapılmasından pek hoşlanmam doğru da bulmam ama temiz-pis öğrenci ayrımı yapabilirim. (K13)"

"Akıllı ve saygilı ögrrenciye daha iyi davranma kaygım var. (K14)"

"Çok etik bulmasam da çalışkan-tembel öğrenci ayrımı yapabilirim. (K15)"

"Soyadı tanıdık geldiğinde veya aynı memleketten olduğum öğrencilere ister istemez daha sicak davranabilirim. (K16)"

“Çalışkan ve terbiyeli öğrencileri ön planda tutacağımı düşünüyorum. (K18)"

Yapılan görüşmeler doğrultusunda öğretmen adaylarının genellikle öğrencilerin akademik başarılarına, cinsiyetlerine, fiziksel özellikleri ve kişilik özelliklerine göre ayrım yapabileceklerini düşündükleri ve bu konuda adaletli olamama kaygıları taşıdıkları söylenebilir.

Etkili öğretmen olamama kaygılarına yönelik bir öğretmen adayı "İyi bir öğretmen, öğretmenliği tam olarak benimser yaşam tarzı haline getir. Sanirsam ben tam olarak ögretmenliği benimsemiyorum. (K10)" ş̧eklinde kaygısını dile getirmiştir. Bir başka öğretmen adayı ise "Öğrencilerin her konuda, benden en iyi şekilde verim alması lazım, bunu her zaman karşılayabilir miyim emin değilim. (K11)" açıklamasında bulunmuştur. 


\section{Ebru KÜLEKÇİ AKYAVUZ}

Bir öğretmen adayı, "Kaç öğrencide ne kadar etki bırakacağımı çok merak ediyor ve kayglanıyorum. (K13)" diye görüş bildirmiştir. Diğer bir öğretmen adayı, "Etkili öğretmen olamama sebebim iyi bir iletişim kuramayacağım ve alan bilgisine yeterli seviyede sahip olamamamdır. (K14)" şeklinde açılamada bulunarak etkili öğretmen olamama kaygısının sebebini dile getirmiştir. K19 kodlu öğretmen adayı ise "Aşırı disiplinli bir insan değilim, çoğu zaman verilen işlerden kaytarma yollarını ararım, bu durumda öğrencileri etkileyebileceğimi düşünmüyorum" açıklamasıyla etkili öğretmen olamama kaygısının sebebini belirtmiştir.

11 öğretmen adayı alay konusu olma kaygısı taşıdığını ifade etmiştir.

90

Bu konuda bir katılımcı "Derste yanlı̧̧ cümle kurarsam, kekelersem ve düşersem öğrencilerin diline düşebilirim. (K16)" şeklinde kaygısını dile getirmiştir. Fiziksel özelliğini vurgulayan bir katılımcı "Biraz kısa boyluyum; ögrrencilerin lakap takmasindan ya da taklidimi yapmasindan korkuyorum. (K15)" şeklinde görüş bildirmiştir. Türkçe öğretmenliği bölümündeki bir öğretmen adayı "Bir Türkçe öğretmeni olarak Türkçeyi etkili bir şekilde kullanamamam, ă̆zımdan yanlış cümleler çıkması, konuşurken anlatım bozukluğu yapmam, tahtada yazımın anlaşılır olmaması ve derste şive ile konuşmam ögrrenciler tarafindan alay konusu olabilir. Bunları yapma konusunda kaygı taşıyorum. (K8)"şeklinde bölümüne özgü olan kaygısını dile getirmiştir.

Akademik yetersizlik konusunda görüşme yapılan öğretmen adayları mesleklerinin gerektirdiği bilgilere yeterli düzeyde sahip olmadıklarını veya bilgileri öğrencilerin seviyesine indirgemede zorluk yaşayacaklarına dair kaygılarını dile getirmişlerdir. Bu konu ile ilgili katılımcılardan biri, "Fizik konularında yetersiz olduğumu düşünüyorum, Fizikteki bazı konuları ben anlamakta zorluk yaşıyorum, bunlar öğrencilere nasıl aktaracağım? (K12)" şeklinde görüş bildirmiştir. Bir başka katılımcı ise "Alan bilgimi yetersiz buluyorum. Alanımız derya deniz, her konuya ulaşamıyoruz, öğrencilerden gelen sorulara yant verememek beni kaygılandırıyor. (K14)" açıklamasında bulunmuştur.

Öğrencilerine rol model olamama kaygısını taşıyan öğretmen adayları bu kaygılarını şu şekilde dile getirmişlerdir:

"Kendine güvenen bir insan duruşu sağlamadığım için öğrencilere iyi bir model olacağımı düşünmüyorum. (K15)" 


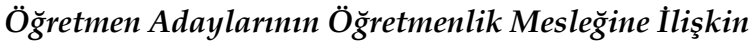 \\ Kaygılarinin Belirlenmesi
}

\begin{abstract}
"Saçlarımı uzatmayı ve bağlamayı seviyorum, günlük hayatımda öğretmenlik mesleğini temsil etmeyen kıyafetler giymiyorum. Ayrıca sigara, alkol durumlarım da var, sanırsam iyi bir model değilim. (K10)"
\end{abstract}

Katılımcılardan iki kişi ilerleyen zamanlarda öğretmenlik mesleğinden sıkılabilme kaygısı taşıdıklarını ifade etmişlerdir. K20 kodlu katılımcı bu kaygısını şu şekilde dile getirmiştir: "Okulöncesi öğretmenliğini seviyorum, çocukları da seviyorum şöyle bir kaygı taşıyorum bu mesleği uzun süre sürdürebilir miyim, bir süre sonra çocuklarla sürekli vakit geçirmekten sıkılır mıyım, hep aynı şeyleri yapmak sıkıcı olur mu, düşünsenize bir sinıfta 15-20 çocuk ve her gün onlarn oyun arkadaşı gibi oyun oynuyorsunuz emekli oluncaya kadar..."

Genel itibari ile görüşme yapılan öğretmen adaylarının öğretmenlik mesleğine ilişkin bireysel kaygılar taşıdığı ve bu kaygıların temelinde karakter ve kişilik yapılarının, vicdani özelliklerinin ve akademik yetersizliklerinin etkili olduğu söylenebilir.

Öğretmen adaylarının öğretmenlik mesleğine yönelik öğretim süreci ile ilgili kaygıları ve alt temaları Tablo 3'te verilmiştir.

Tablo 3. Öğretim Süreci ile ilgili Kaygılar Teması ve Alt Temalar

\begin{tabular}{|c|c|c|c|}
\hline Tema & Alt Tema & Katılımcılar & $\mathbf{n}$ \\
\hline \multirow{4}{*}{$\begin{array}{l}\text { Öğretim } \\
\text { Süreci ile } \\
\text { ilgili } \\
\text { Kaygılar }\end{array}$} & $\begin{array}{l}\text { Zamanı iyi } \\
\text { yönetememe }\end{array}$ & $\begin{array}{l}\text { K1, K2, K6, K7, K8, K9, K11, K12, } \\
\text { K13, K14, K15, K16, K17, K18, K19, } \\
\text { K20 }\end{array}$ & 16 \\
\hline & Sınıf yönetimi & $\begin{array}{l}\text { K1, K2, K3, K4, K5, K6, K9, K11, } \\
\text { K12, K13, K14, K15, K17, K18, K19 }\end{array}$ & 15 \\
\hline & $\begin{array}{l}\text { Öğretim sürecini } \\
\text { etkili düzenleyememe }\end{array}$ & $\begin{array}{l}\text { K1, K2, K3, K4, K5, K6, K9, K10, } \\
\text { K11, K14, K15, K17 }\end{array}$ & 12 \\
\hline & $\begin{array}{l}\text { Dersi monoton hale } \\
\text { getirme }\end{array}$ & K1, K5, K10, K11, K13, K14, K17 & 7 \\
\hline
\end{tabular}

Tablo 3'te öğretmen adaylarının görüşleri doğrultusunda öğretim süreci ile ilgili kaygılar teması ve alt temaları yer almaktadır. Öğretim süreci ile ilgili kaygılar zamanı iyi yönetememe (16), sınıf yönetimi (15), öğretim sürecini etkili düzenleyememe (12) ve dersi monoton hale getirme (7) alt temalarından oluşmaktadır. Öğretmen adayları sınıf içinde zamanı etkili kullanabilme konusunda kaygılar 


\section{Ebru KÜLEKÇİ AKYAVUZ}

taşıdıklarını sıklıkla vurgulamışlardır. Bu konuda okulöncesi öğretmenliği bölümünde bir öğretmen adayı "Etkinliğin süresini ayarlayamamak beni kaygılandırıyor. Bazen öğrenciler ısrarla ayn oyunu birkaç defa oynamak istiyorlar, onlarn kıramam diye düşünüyorum, bu sebeple bana ekstradan zaman gerekecek. (K20)" şeklinde kaygısını dile getirmiştir. Bir başka katılımcı "Dersi anlatmaya başladığımda toparlama yapmayı unutabiliyorum ya da etkinliklerim önceden planladığımdan daha uzun sürüyor. Bunun deneyimsiz olmamdan kaynaklandığını düşünüyorum. (K12)" açıklamasında bulunmuştur. Başka bir katılımcı "Öğrencilerden gelen sorularn cevaplamam gerekir, onlarn es geçemem, onlarn küstüremem. Bu da sınıftaki zamanımı etkileyebilir. (K13)" şeklinde görüşünü

Sınıf yönetimi ile ilgili kaygılar da öğretmen adayları tarafından sıklıkla dile getirilmiştir. Bu alt temaya ait görüşler şu şekildedir:

"Özgüven eksikliğim her yerde karşıma çıkıyor, sımıfı da bu sebeple iyi yönetmeyесеğimi düşünüyorum. (K19)"

“Bir branş öğretmeni olacağımdan ötürü tüm öğrencileri tamımamaktan dolayı nasıl bir yol izleyeceğimi bilememekten kaynaklı kaygı taşıyorum. (K9)"

"Sinıftaki gürültü ortamı ile ve yaramaz öğrencilerle nasıl baş edebileceğim konusunda kaygiliyım. (K6)"

"Otoriter bir yapıya sahip değilim, sınıfı yönetebilir miyim bilmiyorum. (K5)"

“Çocuklara sözümü geçiremezsem, sımıfa hakimiyet kuramazsam... (K4)"

"Kontrolü sağlarken aşırı sert olmaktan korkuyorum. (K2)"

"Merhametli ve güler yüzlü olmamdan ötürü sinıfta otorite kuramayacağımı düşünüyorum. (K18)"

"Deneyimsiz olduğumdan dolayı çok yaramaz bir sinıfı yönetemeyeceğimi düşünüyorum. (K13)"

"Çocukları sevdiğ̈im için onlara aşırı bağlanıyorum, bu yüzden sınıfta otorite kurmada kaygilarm var. (K20)" 


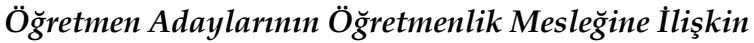 \\ Kaygılarinin Belirlenmesi}

Öğretmen adaylarının görüşleri dikkate alındığında genelde yeterli deneyime sahip olmamaları, kendi kişilik yapıları ve öğrencilerin kişilik yapılarından dolayı sınıfı etkili bir şekilde yönetememe kaygısı taşıdıkları söylenebilir.

Öğretim sürecini etkili düzenleyememe alt teması ile ilgili bir öğretmen adayı "Mesleki yetersizlik ve deneyimsizliğimden dolayı derslerimi nasıl tasarlayıp nasıl sunacağım konusunda endişelerim var. (K10)" şeklinde görüş bildirmiştir. Bir diğer katılımcı ise "Anlattıklarımın anlaşılmaması beni dersten soğutur. Alanımda hangi yöntemi daha etkili kullanacağımı bilmediğim için kaygılıyım. (K15)" açıklamasında bulunmuştur. Bir katılımcı da öğrenci boyutuna vurgu yaparak "Sınıfimda her zekâ düzeyinde ve çeşidinde öğrenci olacağı için hepsine ayrı ayr yöntem kullanma becerisine sahip olmadı̆̆ımı düşünüyorum. (K1)" demiştir.

Öğretim süreci ile ilgili kaygılar temasında en son alt teması dersi monoton hale getirme alt temasıdır. Katılımcılardan bazıları derslerinde hep aynı yöntemleri kullanmalarının, her yıl aynı konuları işlemelerinin monotonluğa sebep olacağın ifade etmişlerdir. K13 kodlu katılımcı bu kaygısını şu şekilde dile getirmiştir: “... benim anlattı̆̆ım yöntem her öğrenciye hitap etmeyebilir, bu yüzden sinıfin hepsi için olmasa da bazı öğrenciler için monoton bir dersim olabilir." Kendi özelliğinden kaynaklı dersi monoton hale getirebileceğini vurgulayan bir katılımcı ise, "Çok esprili bir yapıya sahip değilim ve ses tonum da çok kısık olduğundan derslerimin sıkıcı olacağından endişeleniyorum. (K17)" şekline açıklamada bulunmuştur.

Öğretim süreci ile ilgili kaygılar temasında öğretmen adaylarının ders saatini etkili kullanamama, sınıfı yönetememe, etkili bir öğretim süreci sunamama, dersi sıkıcı hale getirme şeklinde kaygılar taşıdıkları ve bu kaygılarının sebebi olarak da deneyimsiz olmaları, pedagojik bilgilerinin yetersiz olması ve kişilik yapılarından kaynaklı olduğu söylenebilir.

Öğrenci merkezli kaygılar teması ile ilgili analiz sonuçları Tablo 4'te sunulmuştur. 
Ebru KÜLEKÇİ AKYAVUZ

Tablo 4. Öğrenci Merkezli Kaygılar Teması ve Alt Temalar

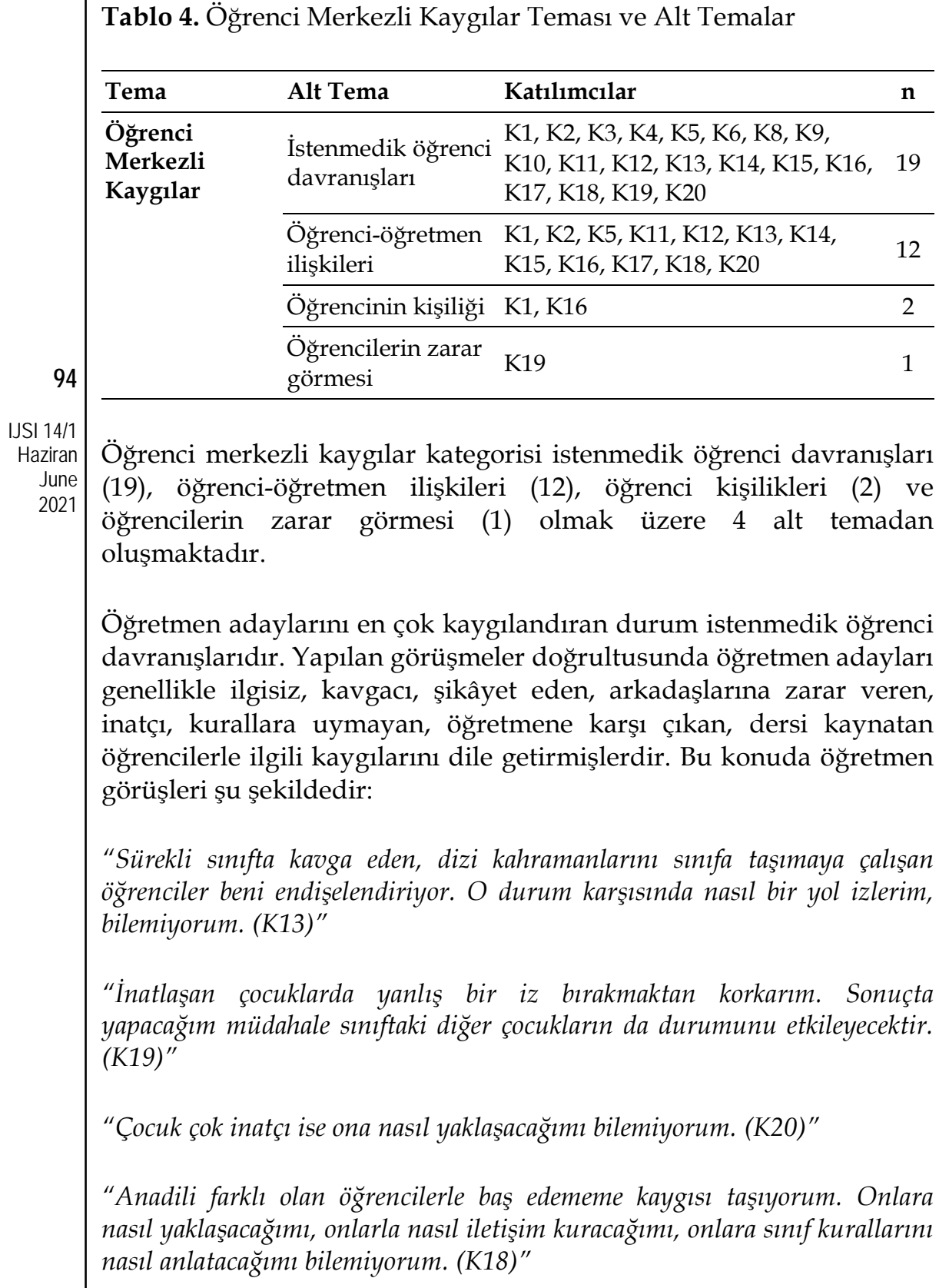




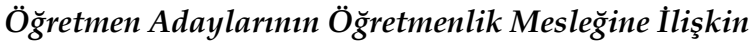 Kaygılarınin Belirlenmesi}

"Kötü sözler söyleyen ve kavga eden öğrencilere karşı öfke kontrolümü sağlayamamaktan endişeliyim. (K16)"

"Kavga eden, benim anlattıklarımla dalga geçen, kesinlikle söz dinlemeyen ögrencilerle karşılaşmaktan korkuyorum. (K15)"

“Çok konuşan, bă̆ıran, yersiz yere izinsiz ayă̆a kalkan, arkadaşlarına zarar veren öğrencilere nasıl tepki vereceğim konusunda endişeliyim. (K12)"

Öğretmen adaylarının istenmedik öğrenci davranışları ile ilgili görüşleri dikkate alındığında genellikle yeterli deneyime sahip olmamalarından ve nasıl bir öğrenci profili ile karşılaşacaklarını bilmemelerinden kaynaklı kaygılar yaşadıkları söylenebilir.

Öğrenci öğretmen ilişkileri alt temasında ise görüşmeye katılan öğretmen adaylarından biri, "Stajlarda çocuklarla çocuk oluyorum, onlara çok yakın davranıyorum, onlar da beni çok ciddiye almıyorlar, bu durumum 3. Sınıftan beri devam ediyor. (K20)" şeklinde kaygısını dile getirmiştir. Bir başka öğretmen aday1; "Öğrencilerle daha yakından ilgilenmek istiyorum, onlara kızamıyorum ve özel bir ilgi göstermek istiyorum. Bu, sanırsam sorunlar oluşturacak. (K11)" açıklamasında bulunmuştur. Farklı öğrenci özelliklerine vurgu yapan bir katılımcı "Özel gereksinime sahip olan öğrencilere (görme, işitme, otizm vs.) nasıl yaklaşacă̆ımı bilmiyorum. Onları incitmekten korkarım. (K12)" diyerek görüşünü açıklamıştır. K17 ve K16 kodlu katılımcılar ise çok merhametli ve güler yüzlü oldukları için suiistimal edileceği kaygısı taşıdıklarını belirtmişlerdir. Öğretmen öğrenci iletişimi alt temasından genel anlamda ögrretmen adaylarının öğrenci-öğretmen çizgisini korumaya yönelik kaygılarının olduğu söylenebilir.

Öğretmen adaylarının kurumsal boyutta taşıdıkları kaygılarla ilgili analiz sonuçları Tablo 5' te verilmiştir. 


\section{Ebru KÜLEKÇİ AKYAVUZ}

Tablo 5. Kurumsal Kaygilar Teması ve Alt Temalar

\begin{tabular}{|c|c|c|c|}
\hline Tema & Alt Tema & Katılımcılar & $\mathbf{n}$ \\
\hline \multirow[t]{5}{*}{$\begin{array}{l}\text { Kurumsal } \\
\text { Kaygılar }\end{array}$} & $\begin{array}{l}\text { Velilerin } \\
\text { özellikleri }\end{array}$ & $\begin{array}{l}\mathrm{K} 1, \mathrm{~K} 2, \mathrm{~K} 3, \mathrm{~K} 4, \mathrm{~K} 6, \mathrm{~K} 7, \mathrm{~K} 8, \mathrm{~K} 9, \mathrm{~K} 10, \\
\mathrm{~K} 11, \mathrm{~K} 12, \mathrm{~K} 13, \mathrm{~K} 14, \mathrm{~K} 15, \mathrm{~K} 16, \mathrm{~K} 17, \mathrm{~K} 18, \\
\mathrm{~K} 19, \mathrm{~K} 20\end{array}$ & 19 \\
\hline & Okul yönetimi & $\begin{array}{l}\text { K1, K3, K4, K8, K10, K11, K12, K13, K14, } \\
\text { K15, K16, K17, K18, K20 }\end{array}$ & 14 \\
\hline & $\begin{array}{l}\text { Meslektaş } \\
\text { ilişkisi }\end{array}$ & K2, K6, K11, K12, K13, K15, K17, K20 & 8 \\
\hline & $\begin{array}{l}\text { Okulun } \\
\text { çevresi }\end{array}$ & $\mathrm{K} 1, \mathrm{~K} 2$ & 2 \\
\hline & $\begin{array}{l}\text { Fiziki } \\
\text { imkânlar }\end{array}$ & $\mathrm{K} 2, \mathrm{~K} 14$ & 2 \\
\hline
\end{tabular}

Kurumsal kaygılar teması velilerin özellikleri (19), okul yönetimi (14), meslektaş ilişkisi (8), okulun çevresi (2) ve fiziki imkânlar (2) alt temalarından oluşmaktadır. Kurumsal kaygılar temasında en çok tekrar edilen alt tema velilerin özellikleridir. Görüşmeye katılan öğretmen adaylarının büyük çoğunluğu öğrenci velileri ile ilgili kaygılarını dile getirmişlerdir. Bu konu ile ilgili görüşler şu şekildedir:

"Beni yetersiz görüp çocuğu üzerinden bana baskı yapmaya çalışan velilerden korkarm. (K13)"

"Çok yüksek beklentisi olan ve hiç beklentisi olmayan velilere karşı kaygiliyım. (K15)"

"Memnuniyetsiz davranan birçok veli var ve eleştirel davranmalar beni kaygilandirir. (K16)"

"Öğrencinin başarısızlı̆̆ ve davranış sorunlarından dolayı kendini suçlamayıp bana hesap soran velilerle baş edememekten korkuyorum. (K17)"

"Çocuklarn ile hiç ilgilenmeyip tüm ilgiyi öğretmenden bekleyen velilerle karşllaşmak beni korkutuyor. (K9)"

“Çocuğunun sürekli hakl olduğunu düşünen veliler... (K8)" 


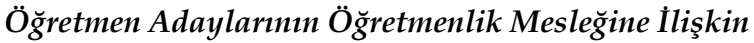 \\ Kaygılarinin Belirlenmesi}

"Çocuğunun sorun ve sorumluluklarından bihaber olan velilerle karşılaşmam diye umuyorum. (K7)"

"Aşır mükemmeliyetçi veliler, hiçbir şeyden memnun kalmaz her şeyi eleştirip her şeye müdahale etmeye çalışırlar. Böyle bir şeyle karşılaşmak istemem. (K3)"

"Eksik bilgisi olan ancak çok şey bildiğini zannedip sürekli bana öneri başliğı altında emirler yă̆dırmaya çalışan veliler... (K2)"

"Aşırı ilgisiz veya çok paranoyak velilerle karşılaşmaktan korkuyorum. (K1)"

"Benim nazarımda bütün veliler öğrencilerde değil de öğretmende suç ararlar. Bu yönde kaygılarım var. (K18)"

"Kaygılı-kaygısız, bilgili-bilgisiz şeklinde uç noktalarda olan öğrenci aileleri beni kaygilandırır. (K10)"

"Yüksek eğitim seviyesine sahip velilerin dersimin işlenişine karışması beni kaygılandırır. (K14)"

Öğretmen adaylarının öğrenci velilerine yönelik görüşleri incelendiğinde genellikle aşırı derecede ilgili veya ilgisiz veliler, bilgili olduğunu sürekli vurgulayıp öğretmenin yaptığı işe müdahalede bulunan veliler, kendisinde sorun aramayıp öğretmeni suçlayan velilerle öğretmenlik mesleğinde karşılaşmak konusunda kaygı taşıdıkları söylenebilir.

Kurumsal kaygılar temasından okul yönetimi alt temasında öğretmen adayları okul yöneticileri ile ilgili taşıdıkları kaygıları dile getirmişlerdir. Bu konuda bir Türkçe öğretmeni adayı, "Tüm resmi günlerde Türkçe öğretmenleri muhakkak ki program düzenliyor. Okul müdürlerinin bu tür işleri okulda diğer öğretmenler yokmuş gibi sürekli Türkçe öğretmenlerine vermeleri benim iş yükümü artırır. (K8)" şeklinde sorumluluklarının artacağı şekilde kaygısını dile getirmiştir. Fen Bilgisi öğretmenleri alanları gereği laboratuvar ortamlarında ders yapmaktadırlar. Bu konu ilgili bir katılımcı "Görevlerimi yerine getirdiğim halde sinufta ve laboratuvarda ders işlememe izin vermeyen okul müdürleri ile anlaşma sağlayamayacă̆ımı düşünüyorum. (K14)" diyerek okul yönetimi ile ilgili kaygısını açıklamıştır. Katılımcıların çoğunluğu okul yöneticileri ile ilgili kaygılarında "adaletli olmama" durumuna 


\section{Ebru KÜLEKÇİ AKYAVUZ}

vurgu yapmışlardır. Bir katılımcı "Uygulama okullarında öğretmenlerden okul müdürlerinin ayrım yaptı̆̆ına dair çok şey duyuyoruz. Ders programının ayarlanmaması, akademik düzeyi düşük sınıfların oluşturulup yönetime yakın olmayan öğretmenlere verilmesi veya onlara daha fazla iş verilmesi vs. bu durumlarla karşılaşmaktan korkuyorum. (K13)" şeklinde kaygısını dile getirmiştir.

Meslektaş ilişkisi alt temasında öğretmen adayları genellikle diğer öğretmenler tarafından iyi iletişim kuramama ve onlar tarafından dışlanma kaygıları taşıdıklarını ifade etmişlerdir. Bu konu ile ilgili bir katılımcı "Alanımda alımlar zor olduğu için ilk yıllarda büyük ihtimalle ücretli öğretmenlik yapacağım. Kadrolu öğretmenlerin beni küçümseyeceğinden veya beni öğretmen olarak görmemelerinden korkuyorum. (K13)" şeklinde görüşünü bildirmiştir. Bir başka katılımcı ise fiziksel özelliklerini vurgulayarak "Tipim öğrenci gibi duruyor, tecrübesizliğim var ve beni tanımıyorlar tabi ki dışlanırım. (K15)" açıklamasında bulunmuştur. Okulöncesi öğretmeni adayı kendi alanı ile ilgili kaygısını şu şekilde dile getirmiştir: "Genelde diğer öğretmenlerin gözünde biz sinıfta oyun oynayıp yemek yiyoruz, akademik alt yapımız yokmuş gibi düşünüyorlar, sanki biz bakıcıyız? Bu şekilde alanımı küçümseyebilirler. (K20)". Okulöncesi bölümünde olan erkek öğretmen adayı ise "Bizim alanı genelde kadınlar tercih ediyor. Erkek sayısı çok az. Öğretmen olduğumda veliler veya diğer öğretmenler tarafindan dışlanacağımı dü̧̈ünüyorum. (K2)" şeklinde kaygısını belirtmiştir.

Okulun çevresi ve fiziki imkânları ile ilgili öğretmen adaylarından biri "Okulun bulunduğu çevreye uyum sağlayamama kaygısını taşıyorum. Ben ..... bölgesinde doğup büyüdüm, kıyafet, saç, stil açısindan daha serbest takılıyorum. Öğretmenlik yapacağım okulun bulunduğu çevrede bu durum nasıl karşılanır bilemiyorum. (K2)" açıklamasında bulunmuştur. Bir başka katılımcı ise "Yapacağım bir etkinlikle ilgili malzemelerin olmaması, internet, projeksiyon, bilgisayar, tahta... (K14)" şeklinde fiziki anlamda yetersizliklere yönelik kaygılarını dile getirmiştir.

Yapılan görüşmeler doğrultusunda öğretmen adaylarının mesleğe atandıktan sonra bireysel, öğrenci, öğretim süreci ve kurumsal boyutlarında kaygılar taşıdıkları ve bu kaygıların genel anlamda çok deneyimleri olmamaları, süreçle ilgili bilgi sahibi olmamaları, kişisel özellikleri gibi nedenlerden kaynaklandığı söylenebilir. 


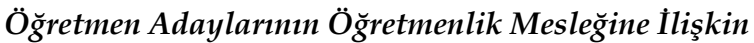 \\ Kaygılarınin Belirlenmesi}

\section{TARTIŞMA ve SONUÇ}

Araştırmanın bu bölümünde elde edilen bulgular alan yazındaki çalışmaların sonuçları ile karşılaştırılarak açıklanmıştır.

Araştırmanın amacı öğretmen adaylarının öğretmenlik mesleğine yönelik kaygılarını ilk elden tespit etmektir. Bu amaç doğrultusunda yapılan görüşmeler sonucunda öğretmen adaylarının öğretmenlik mesleğine yönelik kaygılar taşıdıkları ve bu kaygıların bireysel kaygılar, öğretim süreci ile ilgili kaygılar, öğrenci merkezli kaygılar ve kurumsal kaygilar temalarından oluştuğu belirlenmiştir. Gelecekte neyin, nasıl yaşanılacağının bilinmemesi kaygıyı beraberinde getirmektedir.

Her meslek grubunda olduğu gibi öğretmenlik mesleğine yönelik kaygıların da yaşanması kaçınılmazdır. Öğretmen adaylarının mesleğe yönelik kaygılarının yoğun olduğu zamanların başında mezuniyet aşaması gelmektedir (Atmaca, 2013). Öğretmen adayları bir taraftan derslerden geçip mezun olma kaygısı taşırken bir taraftan da mezun olduktan sonra mesleğe atanıp atanamama kaygısı taşımaktadır. Özellikle bu zaman aralığında öğretmenlik uygulaması, okul deneyimi dersleri ile beraber öğretmenlik mesleğini uzman bir öğretmen gözetiminde icra etmeleri de bu meslekte etkili olacak mıyım şeklinde kaygılarını artırmaktadır. Çalışmada öğretmen adaylarının öğretmenlik mesleğine yönelik olarak bireysel, öğretim süreci ile ilgili, öğrenci merkezli ve kurumsal boyutlarda kayg1 taşıdıkları sonuç elde edilmiştir. Bireysel kaygılar temasında öğretmen adaylarının adaletli yaklaşamama, etkili öğretmen olamama, alay konusu olma, akademik yetersizlik, öğrencilere rol model olamama, meslekten sıkılma ve özel hayatı ihmal etme şeklinde kaygılar taşıdıkları tespit edilmiştir. Özellikle öğretmen adaylarının adaletli olamama konusunda kaygılar taşımaları dikkate değer görülmektedir. Bu konuda görüşme yapılan öğretmen adayları öğrencilere ayrım yapılmasının etik bir davranış olmayacağını dile getirip arkasından kız-erkek, başarılı-başarısız, akıllı-yaramaz öğrencilere yaklaşımları ile ilgili kaygılar taşıdıklarını söylemelerinde bir çelişki söz konusudur. Öğretmen adaylarının öğretmenlerin öğrenciler arasında ayrım yapmalarını etik dışı davranış olarak gördüklerine (Ateş, Çetinkaya-Özdemir ve Taneri, 2019; Pehlivan, Köseoğlu ve Şen, 2018) dair alanyazında çalışmalar mevcuttur. Bu çalışmada da öğrenciler arasında ayrım yapmanın yanlış davranış 
olduğunu vurgulamalarına rağmen yapabileceklerinden endişe duydukları tespit edilmiştir. Bireysel kaygılar temasında etkili öğretmen olamama kaygısı da öğretmen adaylarının çoğunlukla taşıdıkları kaygılar arasındadır. Etkili öğretmenlik üzerine yapılan çalışmalarda etkili öğretmen; istekli ve gayretli olan, kendini sürekli yenileyen, mesleğini seven, güvenilir, bilgili, demokratik, dürüst, adaletli olan, iletişim yeteneğine sahip olan, dersi dikkat çekici hale getiren, öğrencileri güdüleyen, farklı yöntem teknikleri profesyonelce kullanan ve tutarlı davranışlar sergileyen öğretmen olarak tanımlanmaktadır (Demir, 2010; Demirel 2011; Özabacı ve Acat, 2005; Şahin, 2011; Şen ve Erişen, 2002). Mesleği icra eden öğretmenler de dahi etkili öğretmen olamama kaygısı söz konusu iken (Gülay ve Altun, 2017; Gündüz ve Can, 2011; Kozikoğlu ve Senemoğlu, 2018; Toker-Gökçe, 2013) öğretmen adaylarının öğretmenlik mesleğine yönelik yeterli deneyimlerinin olmaması göz önünde bulundurulduğunda sayılan etkili öğretmen özelliklerine sahip olma ile ilgili kaygılar taşımaları normal görünmektedir.

Bireysel kaygılar temasında öğretmen adaylarının akademik alanda kendilerini yeterli hissetmemelerinden kaynaklı kaygılar taşıdıkları tespit edilmiştir. Elde edilen bu sonuç, alanyazında farklı branşlardaki öğretmen adaylarının alan konusunda kendilerini yeterli görmedikleri ile ilgili sonuçları (Coşkun, Gelen ve Öztürk, 2009; Erişen ve Çeliköz, 2003; Ülper ve Bağc1, 2012; Yılmaz, 2019) destekler niteliktedir.

Araştırmada ikinci tema olan öğrenme süreci ile ilgili kaygılar teması zamanı iyi yönetememe, sınıf yönetimi, öğretim sürecini etkili düzenleyememe ve dersi monoton hale getirme kaygilarından oluşmaktadır. Öğretmen adaylarının görüşleri doğrultusunda öğretim süreci ile ilgili yaşadıkları kaygılar çoğunlukla zaman yönetimi ve sınıf yönetimi konusundadır. Öğretmen adayları uygulama derslerinde, konu anlatımlarında verilen süreyi etkili bir şekilde kullanmadıkları ya konuyu yetiştiremedikleri ya da birkaç günlük konuyu bir saatte anlatıp bitirdiklerini ifade etmişlerdir. Ayrıca sınıfa hâkimiyet kuramamak, sınıftaki öğrenciler tarafından dikkate alınmamak şeklinde kaygılar taşıdıkları da tespit edilmiştir. Zaman yönetimi ile ilgili yapılan araştırmalarda öğretmen adaylarının bu konuda kendilerini yeterli hissetmediğine dair sonuçlar elde edilmiştir (Sezen, 2013; Yıldız, 2018). Elde edilen bu sonuçlar alanyazını destekler niteliktedir. Öğretmen adaylarının sınıf yönetimi beceri ve kaygılarına yönelik olarak alanyazında farklı sonuçlar elde 


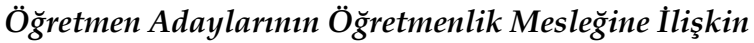 Kaygılarınin Belirlenmesi}

edilmiştir. Araştırmada elde edilen sonuçları destekleyen çalışmalardan birinde öğretmen adaylarının sınıf yönetimi kaygılarının fazla olduğunu tespit edilmiştir (Morton, Vesco, Williams ve Awender, 1997). Önder ve Önder-Öz (2018) tarafından yapılan çalışmada ise öğretmen adaylarının sınıf yönetim kaygılarının düşük düzeyde olduğu sonucu elde edilmiştir. Özay-Köse (2010) tarafından yapılan araştırmada da öğretmen adaylarının genel olarak sınıf yönetimi konusunda kendilerine güvendikleri tespit edilmiştir. Öğretmen adaylarının sınıf yönetimi ve zaman yönetimi konularında kaygilarının olmaları okullarda staj uygulamaları yapmalarına rağmen bu okullarda birebir öğrencilerin sorumluluklarını almamalarından ve bir yıllık uygulamaların deneyim kazanmak için yeterli bir süre olmadığından kaynaklandığı düşünülmektedir.

Öğretmen adaylarının görüşleri doğrultusunda öğrenci merkezli yaşadıkları kaygılar istenmedik öğrenci davranışları, öğrenciöğretmen ilişkileri, öğrenci kişiliği ve öğrencilerin zarar görmesi şeklinde gruplandırılmıştır. Öğretmen adaylarının çoğunlukla istenmedik öğrenci davranışları ile baş etme konusunda kaygı yaşadıkları sonucuna varılmıştır. İstenmeyen öğrenci davranışları öğrencilerin sınıfta öğrenme için ayrılan zamanın azalmasına neden olmakla beraber öğrenmeye engelleyecek olumsuz bir sınıf iklimine de sebebiyet vermektedir (Gökçe, 2014). Bu tür durumlarla baş edebilmek öğretmen adaylarının kaygılarını artırmaktadır.

Araştırmanın dördüncü teması olan kurumsal kaygılar teması velilerin özellikleri, okul yönetimi, meslektaş ilişkisi, okulun çevresi ve fiziki imkânlar ile ilgili kaygılardan oluşmaktadır. Bu tema içerisinde öğretmen adayları tarafından en çok tekrar edilen kaygı veliler ile ilgili kaygılardır. Öğrencilere etkili bir eğitim imkânı sunmada okul yöneticileri ve öğretmenlerin yanı sıra velilere de önemli görevler düşmektedir Öğrenci başarısını sağlamada ve okulun amaçlarına ulaşmasında okul yönetimi, öğretmen, öğrenci ve veliler işbirliği içerisinde hareket etmelidir. Öğretmen-aile arasındaki iletişimin iyi olması öğrencilerin akademik başarısını artırmakla beraber okulda meydana gelebilecek disiplin sorunlarının da azaltabilir (Aslanargun, 2007). Ancak arada oluşabilecek sorunlar, kaygılar öğrencinin performansını olumsuz yönde etkileyecektir. Velinin çocuğuna yaklaşımı, eğitim hayatı, okula karşı tutumu vs. durumlar öğretmenlerde kaygı olarak karşımıza çıkmaktadır. Akgün 
ve Özgür (2014) yapmış oldukları çalışmada öğretmen adaylarının veliler ile ilgili kaygılar taşıdıklarını vurgulamışlardır.

Öğretmen adaylarının okul yönetimi ile sorunlar ve çatışmalar yaşayabileceklerine dair kaygılar yaşadıkları tespit edilmiştir. Özellikle okul yöneticilerinin adaleti sağlayamama, fazla sorumluluklar yükleme konularında sorunlar yaşayacaklarına dair kaygılar taşıdıkları sonucuna ulaşılmıştır. Alanyazında bu sonucu destekleyen çalışmalar mevcuttur. Adıgüzelli (2015) ve Sadıkoğlu, Hastürk ve Polat (2018) tarafından yapılan çalışmalarda da öğretmen adaylarının okul yönetimi merkezli kaygılar taşıdıkları sonucu elde edilmiştir. Öğretmen adaylarının okul yönetim ile ilgili kaygılarının yanı sıra meslektaşları ile ilgili kaygılar taşıdıkları da tespit edilmiştir. Görüşme yapılan öğretmen adaylarının genelde ilk atamalarının ücretli öğretmen olması durumunda veya cinsiyetlerinden ya da branşlarından dolayı diğer öğretmenler tarafından dışlanacaklarını savundukları görülmektedir. Aktaş (2016) ve Sever, Aktaş, Şahin ve Tunca (2015) öğretmen adaylarının görev yapacakları okullarda sosyal ilişkilerle ilgili sorun yaşayabileceklerini düşündükleri sonucuna ulaşılmıştır. Yaşanacak bu sorunların nedenlerinden biri de ücretli öğretmenlik uygulamalarıdır. Bayram (2009); Doğan, Demir ve Turan (2013); Özer (2008); Tuncer (2012) ve Zemrat (2012) tarafından yapılan çalışmalarda okul yöneticilerinin, velilerin, öğrencilerin ve kadrolu öğretmenlerin ücretli öğretmenler hakkında olumsuz tutum ve fikirlere sahip olduğu sonucu elde edilmiştir. Ücretli öğretmenlerle ilgili yapılan çalışmaların sonuçları dikkate alındığında öğretmen adaylarının ücretli öğretmenlik ile ilgili kaygılarının olması olası görülmektedir.

Sonuç itibari ile öğretmen adaylarının öğretmenlik mesleği ile ilgili kaygılarının olduğu ve bu kaygıların yeterli bilgi ve tecrübeye sahip olmamalarından kaynaklandığı söylenebilir. Kayg1 iyi bir şekilde yönetildiğinde bireylerin daha fazla çalışmasına güdülenmesine ve olumsuz olaylara karşı önlem almalarına katkı sağlayacaktır (Akgün, Gönen ve Aydın, 2007). Bu sebeple öğretmen adaylarının yaşadıkları kaygının onları motive edecek, öğretmenlik mesleğine bağlılığını artıracak hale getirilmesi gerekmektedir.

Öğretmen adaylarının öğretmenlik mesleğine yönelik kaygılarını ideal seviyeye getirmek için şu öneriler sunulabilir. 


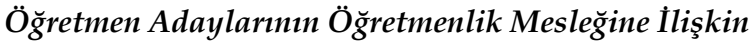 \\ Kaygılarinin Belirlenmesi}

Öğretmen adaylarının görüşleri doğrultusunda öğretmenlik mesleği ile ilgili kaygılarının temelinde mesleğe yönelik uygulama fırsatlarının az olduğu tespit edilmiştir. Bu sorunla ilgili olarak öğretmen adaylarının mevcut uygulama derslerine ek olarak gerçek sinıflarda daha fazla tecrübe kazanmalarına yönelik uygulamaların olması daha etkili olacaktır.

Öğretmen adaylarının üniversite eğitimleri esnasında okullarda görev yapan öğretmenlerle eşleştirmelerin yapılması ve öğretmenlerin öğretmen adaylarına mentor olarak yardım etmeleri, öğretmen adaylarının öğretmenlik mesleğine yönelik kaygılarının azaltılmasına katkı sağlayabilir.

Öfke yönetimi, kriz yönetimi, kaygı yönetimi, özgüven geliştirme eğitimleri gibi eğitimler öğretmen adaylarına eğitim sürecinde verilebilir.

Araştırma sonucunda yapılacak çalışmalara yönelik olarak şu öneri sunulabilir:

Öğretmen adaylarının hizmet öncesi ve hizmet içinde taşıdıkları kaygılar ve bu kaygıların nedenlerine yönelik boylamsal çalışmaların alana kazandırılmasına ihtiyaç duyulmaktadır. 


\section{Ebru KÜLEKÇİ AKYAVUZ}

\section{KAYNAKLAR}

Adıgüzelli, Yaşar (2015). "Examination of Occupational Concern of PreService Teachers Based on Various Variables in Turkey". Educational Research and Reviews, 10(4), 397-402. (Erişim Adresi: https://eric.ed.gov/?id=EJ1062352).

Akgün, Abuzer; Gönen, Selahattin; Aydın, Murat (2007). “İlköğretim Fen ve Matematik Öğretmenliği Öğrencilerinin Kayg1 Düzeylerinin Bazı Değişkenlere Göre İncelenmesi". Elektronik Sosyal Bilimler Dergisi, 6(20), 283299. (Erişim Adresi: https://dergipark.org.tr/tr/download/articlefile/69948).

Akgün, Fatma; Özgür, Hasan (2014). “Bilişim Teknolojileri Öğretmen Adaylarının Öğretmenlik Mesleğine İlişkin Tutumları ile Mesleki Kaygılarının İncelenmesi". Eğitimde Kuram ve Uygulama, 10(5), 1206-1223. (Erişim Adresi: https://dergipark.org.tr/tr/download/article-file/63441).

Aktaş, Bilge Çam (2016). “Sınıf Öğretmeni Adaylarının Mesleki Yaşamlarında Karşılaşabileceklerini Düşündükleri Sorunlar". Mehmet Akif Ersoy Üniversitesi Eğitim Fakültesi Dergisi, 16(38), 16-30. (Erişim Adresi: https://dergipark.org.tr/tr/download/article-file/227245).

Aslanargun, Engin (2007). “Okul-Aile İşbirliği ve Öğrenci Başarısı Üzerine Bir Tarama Çalışması". Manas Üniversitesi Sosyal Bilimler Dergisi, 18, 119-135. (Erişim Adresi: http://journals.manas.edu.kg/mjsr/oldarchives /Vol09_Issue18_2007/564-1510-1-PB.pdf).

Ateş, Seyit; Çetinkaya-Özdemir, Ezgi; Taneri, Ahu (2019). “İstenmeyen Öğretmen Davranışlarına İlişkin Öğretmen Adaylarının Görüşleri". Bolu Abant İzzet Baysal Üniversitesi Eğitim Fakültesi Dergisi, 19(1), 37-56. doi. 10.17240/aibuefd.2019.19.43815-423291.

Atmaca, Hasan (2013). “Almanca, Fransızca ve İngilizce Öğretmenliği Bölümlerinde Okuyan Öğretmen Adaylarının Mesleki Kaygıları”. Turkish Studies, $\quad 8(10), \quad 67-76.6$ (Erişim https://arastirmax.com/tr/system/files/dergiler/79199/makaleler/8/10/ar astirmax-almanca-fransizca-ingilizce-ogretmenligi-bolumlerindeokuyanogretmen-adaylarinin-mesleki-kaygilari.pdf).

Bayram, Gülçin (2009). “Öğretmenlerin İstihdam Biçimi Farklılıkları ve Yarattı̆̆1 Sorunlar: Ankara'da Çalışan Sözleşmeli ve Ücretli Öğretmenlerin Görüşlerine Dayalı Bir Araştırma”, (Yayınlanmamış Yüksek Lisans Tezi), Ankara Üniversitesi.

Coşkun, Eyyup; Gelen, İsmail; Öztürk, Emine P. (2009). “Türkçe Öğretmen Adaylarının Öğretimi Planlama, Uygulama ve Değerlendirme Yeterlik Algiları". Mustafa Kemal Üniversitesi Sosyal Bilimler Enstitüsü Dergisi, 6(12), 


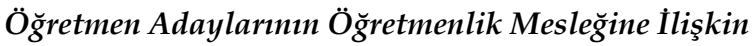 Kaygılarnin Belirlenmesi}

140-163. (Erişim Adresi: http://www.acarindex.com/dosyalar/makale /acarindex-1423909474.pdf).

Çakmak, Özlem; Hevedanlı, Murat (2004). “Biyoloji Öğretmen Adaylarının Kaygılarını Etkileyen Etmenler". 13. Ulusal Eğitim Bilimleri Kurultayı, 6-9 Temmuz, İnönü Üniversitesi Eğitim Fakültesi, Malatya.

Çekmez, Erdem; Yıldız, Cemalettin; Bütüner, Suphi Ö. (2012). "Phenomenographic Research Method". Necatibey Faculty of Education Electronic Journal of Science and Mathematics Education, 6(2), 77-102. (Erişim Adresi: https://dergipark.org.tr/tr/download/article-file/39858).

Demir, Semra (2010). “Öğretim Etkinliklerinin Planlanması”. Erbaş, D. (Ed.), Sınıfta Etkili Öğretim ve Yönetim, Ankara: Data Yayınevi.

Demirel, Özcan (2011). Öğretim İlke ve Yöntemleri Öğretme Sanatı. Ankara: Pegem A Yayıncilik.

Doebler, Leland K.; Roberson, Terry G. (1987). “A Study of Common Problems Experienced by Secondary Student Teachers". Education, 107(3), 234-243. Erişim Adresi: http://eds.a.ebscohost.com/eds/pdfviewer / pdfviewer?vid=2\&sid=8104a1c6-d8a0-4a90-a15c-83992c07cfe5\%40sdc-vsessmgr03.

Doğan, Soner; Demir, Selçuk B.; Turan, Nazan (2013). “Ücretli Öğretmenlik Uygulamasının Değerlendirilmesi". Turkish Studies, 8(12), 371-390. doi : http://dx.doi.org/10.7827/TurkishStudies.5850.

Ensari, Hoşcan (2000). "Yılgınlık ile Kayg1 ve Öğretmen Tutumlarının İlişkisi". Amme İdaresi Dergisi, 33(4), 85-102.

Erden, Münire (1998). Öğretmenlik Mesleğine Giriş. Ankara: Alkım Yayınları.

Erişen Yavuz; Çeliköz, Nadir (2003). “Öğretmen Adaylarının Genel Öğretmenlik Davranışları Açısından Kendilerine Yönelik Yeterlilik Algıları". Türk Ĕgitim Bilimleri Dergisi, 1(4), 427-439. (Erişim Adresi: https://dergipark.org.tr/en/download/article-file/256440).

Ersoy, Figen (2016). “Fenomenoloji”. A. Saban, A. Ersoy (Eds.), Eğitimde Nitel Araştırma, 51-105, Ankara: Anı Yayıncılık.

Fuller, F. Fuller (1969). "Concerns of Teachers: A Developmental Conceptualization". American Education Research Journal, 6, 207-226. doi: 10.3102/00028312006002207.

Göçmen, Gülşah B.; Balgalmış, Esra (2005). “Gaziosmanpaşa Üniversitesi Sınıf Öğretmenliği ve Müzik Öğretmenliği Bölümü Öğretmen Adaylarının Akademik Başarısıyla Öğretmenliğe İlişkin Tutumları ve Kpss Kaygıları Arasındaki İlişki". XIV. Ulusal Ĕ̆itim Bilimleri Kongre Kitabı, Cilt I, 489-494, XIV. Ulusal Eğitim Bilimleri Kongresi, Pamukkale Üniversitesi, Denizli. 


\section{Ebru KÜLEKÇİ AKYAVUZ}

Gökçe, Feyyat (2014). Sinıfta Öğrenme ve Öğretme Sürecinin Yönetimi. Ankara: Pegem Akademi.

Gülay, Ahmet; Altun, Taner (2017). “Göreve Yeni Başlayan Öğretmenlerin Yeterlik Algılarının ve Karşılaştıkları Sorunların Belirlenmesi". Dicle Üniversitesi Ziya Gökalp Eğitim Fakültesi Dergisi, 31, 738-749. doi: 10.14582/DUZGEF.1837.

Gündüz, Yüksel; Can, Ertuğrul (2011). “Öğretmenlerin Eğitim Sistemi ve Uygulamalarına İlişkin Güncel Sorunları Algılama Düzeylerinin İncelenmesi". Türk Eğitim Bilimleri Dergisi, 9(4), 745-774. (Erişim Adresi: https://dergipark.org.tr/en/download/article-file/256198).

Kaya, Ali; Büyükkasap, Erdoğan (2005). “Fizik Öğretmenliği Programı Öğrencilerinin Profilleri, Öğretmenlik Mesleğine Yönelik Tutum ve Endişeleri: Erzurum Örneği”. Kastamonu Ĕ̆itim Dergisi, 13(2), 367-380.

Kozikoğlu, İshak; Senemoğlu, Nuray (2018). “Mesleğe Yeni Başlayan Öğretmenlerin Karşılaştıkları Güçlükler: Nitel Bir Çözümleme". Eğitimde Nitel Araştırmalar Dergisi/ Journal of Qualitative Research in Education, 6(3), 341-371. doi:10.14689/issn.2148-2624.1.6c3s16m.

Morton, L. L.; Vesco, R.; Williams, N. H.; Awender, M. A. (1997). “Student Teacher Anxieties Related to Class Management, Pedagogy, Evaluation, and Staff Relations". British Journal of Educational Psychology, 67, 69 - 89. doi: 10.1111/j.2044-8279.1997.tb01228.x.

Özay Köse, Esra (2010). "Sınıf Yönetimine Yönelik Öğretmen Adaylarının Görüşleri”. Çukurova Üniversitesi Eğitim Fakültesi Dergisi, 3(39) 20-27. (Erişim Adresi: $\quad$ http://www.acarindex.com/dosyalar/makale/acarindex1423874849.pdf).

Önder, Emine; Önder Öz, Yurdagül (2018). "Variables that Predict Classroom Management Anxiety and Classroom Management Anxieties Level of PreService Teachers". Pegem Eğitim ve Öğretim Dergisi, 8(4), 645-664. doi: 10.14527/pegegog.2018.025.

Özabacı, Nilüfer; Acat, Bahaddin, (2005). “Öğretmen Adaylarının Kendi Özellikleri ile İdeal Öğretmen Özelliklerine Dönük Algılarının Karşılaştırılması". Kuram ve Uygulamada Eğitim Yönetimi Dergisi, 11(42), 211236. (Erişim adresi: file:/ / C:/Users/User/Downloads/385-735-1-SM.pdf).

Özer, Ebru (2008). “Kadrolu ve Kadrosuz İlköğretim Öğretmenlerinin Birbirleri ve Meslekleri Hakkındaki Görüşleri", (Yayınlanmamış Yüksek Lisans Tezi), Marmara Üniversitesi, İstanbul.

Pehlivan, Hülya; Köseoğlu, Pınar; Şen, Zeynep (2018). “Öğretmen Adaylarının Öğrenme Ortamlarında Uygulanan Ödül, Ceza ve Ayrımcılığa İlişkin Görüşleri". Elementary Education Online, 17(4), 2091-2109. doi: 10.17051/ilkonline.2019.506970. 


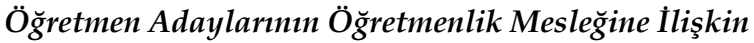 Kaygılarinin Belirlenmesi}

Sadıkoğlu, Murat, Hastürk, Gamze ve Polat, Oğuzhan, (2018). “Fen Bilimleri Öğretmen Adaylarının Mesleki Kaygı Düzeyleri". Uluslararası Sosyal Araştırmalar Dergisi, 11(56), 629-637. doi: http://dx.doi.org/10.17719/ jisr.20185639035.

Sever, Demet; Aktaş, Bilge Ç.; Şahin, Senar A.; Tunca, Nihal (2015) "Pedagojik Formasyon Sertifika Programı Öğrencilerinin Öğretmenlik Mesleğine Başladıklarında Karşılaşabileceklerini Düşündükleri Sorunlar". Anadolu Journal of Educational Science International, 5(2), 1-23. doi: 10.18039/ajesi.35496.

Sezen, Abdulvahit (2013). "İlahiyat Fakültesi Öğrencilerinin Zaman Yönetimi Becerilerinin İncelenmesi”. Akademik Bakış Dergisi, 38, 1-18. (Erişim Adresi: https://www.acarindex.com/dosyalar/makale/acarindex-1423867734.pdf).

Smith, Bettye P. (2000). "Emerging Themes in Problems Experienced by Student Teachers: A Framework for Analysis". College Student Journal, 34(4), 633. (Erişim Adresi: http://eds.b.ebscohost.com/eds/detail/detail?vid $=1 \&$ sid $=808 \mathrm{c} 4066-3820-4369-\mathrm{a} 603-\mathrm{da} 3608 \mathrm{a} 8 \mathrm{fe} 30 \% 40 \mathrm{pdc}-\mathrm{v}-\mathrm{sessmgr} 05 \& \mathrm{bdata}=$ Jmxhbmc9dHImc210ZT11ZHMtbGl2ZQ\%3d\%3d\#AN=4044554\&db=trh).

Şahin, Ayfer (2011). “Öğretmen Alg1larına Göre Etkili Öğretmen Davranışları". Ahi Evran Üniversitesi Eğitim Fakültesi Dergisi, 12(1), 239-259. (Erişim adresi: http://kefad.ahievran.edu.tr/InstitutionArchiveFiles /f44778c7-ad4a-e711-80ef-00224d68272d/d1a3a581-af4a-e711-80ef00224d68272d/Cilt12Sayi1/JKEF_12_1_2011_239_259.pdf).

Şen, H. Şenay; Erişen, Yavuz (2002). “Öğretmen Yetiştiren Kurumlarda Öğretim Elemanlarının Etkili Öğretmenlik Özellikleri”. Gazi Üniversitesi Eğitim Fakültesi Dergisi, 22(1), 99-116. (Erişim adresi: http:// www.gefad.gazi.edu.tr/tr/download/article-file/77439).

Şişman, Mehmet (2007). Eğitim Bilimine Giriş. Ankara: Pegem Akademi.

Taşğın, Özden (2006). “Beden Eğitimi Ve Spor Yüksekokulunda Okuyan Öğretmen Adaylarının Mesleki Kaygı Düzeylerinin Bazı Değişkenler Açısından İncelenmesi”. Kastamonu Eğitim Dergisi, 14(2), 679-686.

Toker-Gökçe, Asiye (2013). “Sınıf Öğretmenlerinin Adaylık Dönemlerinde Yaşadıkları Mesleki Sorunlar". Dicle Üniversitesi Ziya Gökalp Eğitim Fakültesi Dergisi, 21, 137-156. (Erişim Adresi: https://dergipark.org.tr/ en/download/article-file/786874).

Tuncer, Murat (2012). “Türkiye'deki Kadrosuz Öğretmen İstihdamının Kadrosuz İstihdam Edilen Öğretmen Görüşlerine Göre Değerlendirilmesi". Gaziantep Üniversitesi Sosyal Bilimler Dergisi, 11(3), 797-781. (Erişim adresi: https://dergipark.org.tr/tr/download/article-file/223320).

Tümerdem. Recep (2007). “Dicle Üniversitesi Eğitim Fakültesi Ve FenEdebiyat Fakültesi Kimya Son Sınıf Öğrencilerinin Kaygılarını Etkileyen 


\section{Ebru KÜLEKÇİ AKYAVUZ}

Etmenler". Elektronik Sosyal Bilimler Dergisi, 6(20), 32-45. (Erişim Adresi: http:/ / www.e-sosder.com/dergi/2032-45.pdf).

Türk Dil Kurumu (2019). (Erişim adresi: https://sozluk.gov.tr/).

Ülper, Hakan; Bağc1, Hasan, (2012). “Türkçe Öğretmeni Adaylarının Öğretmenlik Mesleğine Dönük Öz Yeterlik Algiları". Turkish Studies, 7(2), 1115-1131. (Erişim Adresi: http://www.acarindex.com/dosyalar/ makale/acarindex-1423933680.pdf).

Yıldırım, Ali; Şimşek, Hasan (2018). Sosyal Bilimlerde Nitel Araştırma Yöntemleri. Ankara: Seçkin Yayınevi.

Yılmaz, Aynur (2019). “Öğretmen Adaylarının Kariyer Streslerinin Karma Araștırma Yaklaşımı ile İncelenmesi". Türk Spor Bilimleri Dergisi, 2(1), 93-105. (Erişim Adresi: https://dergipark.org.tr/tr/download/article-file/681774). 99. doi: $10.19126 /$ suje.413286.

Zemrat, Rengin (2012). “Okul Öncesi Öğretmenlerinin Okul Yöneticisi, Meslektaşları ve Aileler Bağlamında Algıladıkları Çatışma Durumlarının İncelenmesi". Eğitim ve Bilim, 37 (163), 203-215. 


\section{Öğretmen Adaylarının Öğretmenlik Mesleğine İlişkin \\ Kaygılarinin Belirlenmesi}

\section{SUMMARY}

Purpose and Significance. The aim of this study is to identify the concerns of candidate teachers concerns about teaching profession. In addition, the purpose of this study is to determine the reasons for the concerns of candidate teachers and what kind of practices could be carried out in order to minimize these concerns. Accordingly, the questions to be answered in the study are as follows:

What are the concerns of candidate teachers about teaching profession?

What are the reasons of the professional concerns of candidate teachers?

Obtaining information about the difficulties and concerns of candidate teachers is important in terms of solving these difficulties and concerns (Doebler and Roberson, 1987). Candidate teachers should be free from professional concerns when starting their profession effectively (Taşgın, 2006). This study plays a crucial role in terms of determining the pre-service concerns of candidate teachers who will contribute to the shaping of the next generation and conducting preventive studies to be carried out in order to eliminate these concerns.

Methodology. The study was designed as qualitative research. Phenomenological design was preferred among qualitative research designs. Descriptive phenomenological design is a research design aiming to reveal the experiences and perceptions of individuals according to their perspectives (Ersoy, 2016).

The study group consisted of 20 candidate teachers enrolled in Kilis 7 Aralık University in the fall semester of 2019-2020 academic year. Sample selection was made by using criterion-sampling method among the purposive sampling types.

A semi-structured interview form was prepared to determine the candidate teachers' concerns about their profession. The interview form was prepared by the researcher.

After the interview questions were prepared, candidate teachers from different departments were identified. Interviews were conducted by arranging appointments in the appropriate time periods for the candidate teachers and researchers. A voice recorder was used during the interviews upon receiving the consent of the participants. Interviews with each candidate 
teacher took approximately 35-45 minutes. The interview was conducted in the researcher's office.

The data obtained in the study were analyzed with descriptive analysis method. The data obtained in the descriptive analysis were summarized and interpreted according to the previously determined themes (Yildırım and Şimşek, 2018). In this study, themes were created by considering the concern types for the candidate teachers determined by Fuller (1969).

Results. In line with the first and second problems of the research, it was aimed to determine the candidate teachers' concerns about the teaching profession and the reasons for these concerns. In this context, 4 themes were identified: individual concerns, teaching-related concerns, student-centered
concerns and institutional concerns. The theme of individual concerns of teacher candidates about teaching profession consists of the following sub themes such as not being fair (14), not being effective (14), being mocked (11), academic insufficiency (10), not being positive role model (9), boredom (2) and neglecting their private life (1). Concerns about the teaching process consist of the sub-themes of inability to manage time well (16), classroom management (15), inability to organize the teaching process effectively (12) and to make the course monotonous (7). The student-centered concern category consists of 4 sub-themes: undesired student behaviors (19), studentteacher relations (12) and student personalities (2). The sub themes of institutional concerns consist of the characteristics of parents (19), school management (14), peer relations (8), school environment (2) and physical facilities (2). In general, candidate teachers stated that they did not have sufficient experience as a reason for their concerns, that their pedagogical knowledge was insufficient and that their personality structures were effective.

Discussion and Conclusion. As a result of the interviews, it was determined that the candidate teachers had concerns about the teaching profession and these concerns consisted of individual concerns, teaching-related concerns, student-centered concerns and institutional concerns. In the theme of individual concerns, it was determined that candidate teachers were concerned about not having fair approach, not being an effective teacher, being ridiculed, academic insufficiency, not being a role model for students, boredom from profession and neglecting their private life. In particular, it is noteworthy that candidate teachers have concerns about not being fair. There is a contradiction in the candidate teachers who have been interviewed on this issue, saying that it is not ethical to make discrimination among students and that they have concerns about their approach to male-female, successfulunsuccessful, smart-naughty students. There are studies in the literature that candidate teachers perceive discrimination among students as unethical behavior (Ateş, Çetinkaya-Özdemir and Taneri, 2019; Pehlivan, Köseoğlu and 


\section{Ö̆̆retmen Adaylarının Öğretmenlik Mesleğine İlişkin Kaygılarinin Belirlenmesi}

Şen, 2018). In this study, it has been found that although they emphasize that discriminating among students is not a right behavior, they are concerned about what they can do.

The second theme in the research, concerns about the learning process, consisted of inability of time, classroom management, inability to effectively regulate the teaching process and to make the lesson monotonous. In line with the opinions of candidate teachers, the concerns they have about the teaching process are mostly about time and classroom management. Candidate teachers stated that they did not use the time given effectively in the lectures, they could not manage to finish the subject or they discussed and finished subjects in one hour instead of a few days. It was also determined that they were worried about not being able to dominate the classroom and not being taken into consideration by the students in the classroom. In the researches about time management, it was obtained that the candidate teachers did not see themselves efficient about this subject (Sezen, 2013; Yıld1z, 2018). These results support the literature. Different results were obtained in the literature regarding the classroom management skills and concerns of candidate teachers. In one of the studies supporting the results of the study, it was determined that the candidate teachers were more concerned about classroom management (Morton, Vesco, Williams and Awender, 1997). It has been believed that the reason candidate teachers have concerns about classroom and time management is that they do internship practices in schools but they do not take the responsibilities of one-to-one students in these schools, and one-year practices are not enough to gain experience.

In line with the opinions of candidate teachers, student-centered concerns were grouped as undesired student behaviors, student-teacher relations, student personality and students getting harmed. It was concluded that candidate teachers were mostly concerned about coping with undesired student behaviors. Undesired student behavior not only causes reduction of time left for the students willing to learn in the classroom, but also creates a negative classroom environment eliminating learning (Gökçe, 2014). Being able to cope with such situations increases the candidate teachers' concerns.

The fourth theme of the research, institutional concerns, consists of the characteristics of parents, school management, peer relationship, school environment and physical facilities. Within this theme, the most repeated concern by candidate teachers is about parents. In addition to school administrators and teachers, parents have important responsibilities in providing effective educational opportunities for students. School management, teachers, students and parents should act in cooperation to ensure student success and achieve school goals. Good communication between teacher and family can either increase students' academic achievement or decrease the discipline problems that may occur in the school 


\section{Ebru KÜLEKÇİ AKYAVUZ}

(Aslanargun, 2007). However, problems and concerns that may occur in between will negatively affect student performance. In cases such as Parent's approach to child, education life, attitude towards school, etc. appears to be teachers' concerns. In their study, Akgün and Özgür (2014) emphasized that candidate teachers had concerns about parents.

As a result, it could be noted that the candidate teachers have concerns about the teaching profession and these concerns come from the lack of sufficient knowledge and experience. When anxiety is well managed, it will help individuals to be motivated in further work and to take precautions against negative issues (Akgün, Gönen and Aydın, 2007). For this reason, the

were few opportinities to apply to the profession based on their concer were few opportunities to apply to the profession based on their concerns about the teaching profession. Regarding this issue, it will be more effective to have activities for candidate teachers to gain experience in real classrooms in addition to the existing practice courses.

Matching teachers with candidate teachers working in schools during their university education and assisting candidate teachers as mentors may contribute to reducing candidate teachers' concerns about teaching profession.

The following suggestion could be made for the future studies to be carried out according to this research;

There is a need for longitudinal studies aimed at the candidate and in-service concerns of teacher candidates and the causes of these concerns. 